\title{
IMPLEMENTATION OF STANDARDIZATION AND CERTIFICATION OF SPORT COMPETENCE
}

\begin{abstract}
Muhlisin ${ }^{1}$
Abstract, This study aims to determine the implementation of standardization and certification sports Competencies. Research carried out in several places, namely at the Ministry of Youth and Sports, the office of the Central KONI, and the Office of National Accreditation Institute Sport (LANKOR) This research uses descriptive method. The instrument used is in the form of guidelines for observation, interview and documentation guidelines so that the analysis of data used is descriptive and qualitative analysis. This study concludes that weak management systems implementation of standardization and certification, standardization Synergy implementing agencies, accreditation and certification are still not optimal because the functions and authority of the implementing agencies are still ambiguous. The study also concluded the lack of understanding society sports personality of the implementation of standardization, and certification Competence in sports because it is not supported by a consistent system of accreditation
\end{abstract}

Keyword : Competence, Sport, standardization, Accreditation, Certification

\section{PENDAHULUAN}

PASAL 4 UU No. 3 Tahun 2005 tentang Sistem Keolahragaan Nasional (SKN) mengisyaratkan bahwa yang dimaksud dengan keolahragaan nasional adalah bertujuan untuk memelihara dan meningkatkan kesehatan dan kebugaran, prestasi, kualitas manusia, menanamkan nilai moral dan akhlak mulia, sportivitas, disiplin, mempererat dan membina persatuan dan kesatuan bangsa, memperkukuh ketahanan nasional, serta mengangkat citra, harkat martabat dan kehormatan bangsa dimata dunia.

\footnotetext{
${ }^{1}$ Muhlisin adalah Dosen Fakultas Ilmu Keolahragaan Universitas Negeri Semarang
} 
Tenaga keolahragaan sebagai individu dalam konteks keolahragaan nasional seperti yang tercantum pada ayat (1) yang menyebutkan bahwa, tenaga keolahragaan harus memiliki kualifikasi dan standar yang sesuai dengan kompetensinya sebagai profesi. Menurut Undang-Undang Nomor 3 Tahun 2005 tentang Sistem Keolahragaan Nasional terdapat 14 jenis tenaga keolahragaan, yaitu pelatih, wasit, juri, guru/dosen, promotor, manajer, administrator, pemandu, penyuluh, instruktur, tenaga medis dan paramedis, ahli gizi, ahli biomekanika, psikolog, atau sebutan lain yang sesuai dengan kekhususannya serta berpartisipasi dalam menyelenggarakan kegiatan olahraga. Pelaksanaan standardisasi, akreditasi dan sertifikasi diperlukan untuk meningkatkan kualitas dan kompetensi tenaga keolahragaan sebagai profesi. Peningkatan kualitas dan mutu tenaga keolahragaan akan memberikan dampak signifikan dalam pengembangan keolahragaan nasional dimana tenaga olahraga akan benar-benar menjadi sebuah profesi yang “Terhormat dan bermartabat” dimata masyarakat. Tenaga olahraga tidak lagi menjadi sebuah kegiatan "Kerja bakti” ataupun "Pekerjaan sampingan” selain menjadi guru atau dibawah pekerjaan lainnya.

Berdasarkan data statistik Badan Pusat Statistik (BPS) tahun 2010 tingkat pengangguran di Indonesia masih tinggi. Konsep pengangguran yang digunakan adalah mereka yang belum bekerja dan sedang mencari pekerjaan, atau mempersiapkan usaha atau tidak mencari pekerjaan karena tidak mungkin mendapatkan pekerjaan, atau yang sudah punya pekerjaan tetapi belum mulai bekerja. Pengangguran dengan konsep-definisi tersebut biasa disebut sebagai pengangguran terbuka. Badan Pusat Statistik menyatakan angka pengangguran per Agustus 2009 sebanyak 7,87 persen. Persentase itu diperoleh dari perbandingan angka penganggur sebanyak 8,96 juta orang dibagi angkatan kerja, 113,83 juta orang. Bidang olahraga memiliki 14 profesi tenaga keolahragaan yang memiliki relevansi dalam pengadaan ketenagakerjaan guna mengatasi permasalahan pengangguran di Indonesia.

Selain itu partisipasi pemuda terhadap penyelenggaraan pelatihan tenaga keolahragaan juga masih rendah. Berikut data pertisipasi pemuda dalam pelaksanaan keolahragaan pada tahun 2006-2009. 
Tabel 1.

Pemuda dalam Penyelenggaraan Pelatihan Tenaga Keolahragaan

\begin{tabular}{|c|c|c|c|c|c|}
\hline No & Jenis Pelatihan & 2007 & 2008 & 2009 & Jumlah \\
\hline 1 & TOT Pelatih Tingkat Dasar & 60 & - & - & 120 \\
\hline 2 & TOT Pelatih Tingkat Muda & 60 & 40 & - & 100 \\
\hline 3 & TOT Pelatih Tingkat Madya & 84 & - & - & 84 \\
\hline 4 & TOT Koordinator Relawan olahraga & 119 & - & - & 199 \\
\hline 5 & $\begin{array}{l}\text { TOT Instruktur Pengembangan Terapi } \\
\text { Masage }\end{array}$ & - & 40 & 50 & 90 \\
\hline 6 & Pelatihan Tenaga Laboratorium Olahraga & 40 & - & - & 80 \\
\hline 7 & Pelatihan Masage & 86 & 25 & - & 111 \\
\hline 8 & Pelatihan CPR & 50 & 25 & - & 75 \\
\hline 9 & Pelatihan Cedera Olahraga & - & - & 40 & 40 \\
\hline 10 & Pelatih Analisa Data & - & 50 & 80 & 130 \\
\hline 11 & Pelatihan Tenaga Relawan & 80 & - & - & 80 \\
\hline 12 & Pelatihan Gizi Olahraga & - & 37 & 45 & 82 \\
\hline 13 & Pelatihan Pelatih Tingkat Dasar & 121 & 80 & 67 & 268 \\
\hline 14 & Pelatihan Pelatih Tingkat Muda & 107 & 80 & 40 & 227 \\
\hline 15 & Pelatihan Pelatih Tingkat Madya & - & 42 & - & 42 \\
\hline 16 & Pelatihan Pelatih Fisik Level I Nasional & - & 80 & 130 & 210 \\
\hline 17 & Instruktur Teknis Laboratorium & - & 8 & - & 8 \\
\hline 18 & Administrator Sport Management & 9 & - & - & 9 \\
\hline 19 & Pelatihan Pelatih \& Wasit Catur & 4 & - & - & 4 \\
\hline 20 & Pelatihan Pelatih \& Wasit Woodball & 5 & 5 & 6 & 16 \\
\hline 21 & Pelatihan Pelatih Bowlling & - & 20 & - & 20 \\
\hline 22 & Pelatihan Wasit Panahan & - & 3 & - & 3 \\
\hline 23 & Pelatihan Wasit Silat & - & 22 & - & 22 \\
\hline 24 & Pelatihan Wasit Senam & - & - & 5 & 5 \\
\hline 25 & Pelatihan Laboratorium Olahraga & - & - & 8 & 8 \\
\hline 26 & Strenght \& Condition Level I (ASCA) & 10 & 17 & 37 & 64 \\
\hline 27 & Strenght \& Condition Level II (ASCA) & - & 10 & - & 10 \\
\hline 28 & Magang Pelatih di Luar Negeri & 3 & 2 & - & 5 \\
\hline \multicolumn{2}{|r|}{ Jumlah } & 838 & 586 & 508 & 2112 \\
\hline
\end{tabular}

Sumber : Kemenpora. Penyajian data dan Informasi Kepemudaan dan Keolahragaan tahun 2009. (Jakarta : Kemenpora.2010) 
Asisten Deputi Standardisasi Akreditasi dan Sertifikasi (Asdep SAS) sebagai salah satu asdep di Kementerian Pemuda dan Olahraga yang memiliki tanggung jawab dan wewenang dalam pelaksanaan Standardisasi akreditasi dan sertifikasi di bidang olahraga. Dalam pelaksanaannya Asdep SAS memiliki fungsi untuk melakukan standardisasi sesuai dengan ketentuan UU SKN Nomor 3 Tahun 2005 dan mengacu pada kepada peraturan Pemerintah Nomor 16 tahun 2007 tentang penyelenggaraan olahraga serta adaptasi terhadap pedoman dalam sistem standardisasi nasional keolahragaan sehingga dapat diakui secara nasional maupun internasional.

Beberapa program kerja telah dilakukan oleh Asdep Standardisasi Akreditasi dan Sertifikasi (Asdep SAS) dalam pelaksanaan standardisasi, akreditasi dan sertifikasi tenaga keolahragaan. Diantara program-program yang telah ditempuh oleh Asdep SAS antara lain pembentukan Lembaga Akreditasi Nasional Keolahragaan (LANKOR), perumusan Badan Standardisasi Akreditasi Nasional Keolahragaan (BSANK), pembentukan Lembaga Sertifikasi Kelayakan Prasarana dan Sarana Olahraga (LSKPSO), pembentukan Lembaga Sertifikasi Kompetensi Tenaga Keolahragaan (LSKTK) dan Pembentukan tim asesor kompetensi tenaga keolahragaan.

Selama ini pelaksanaan Standardisasi dan sertifikasi terhadap pelatih olahraga dan tenaga olahraga lainnya masih belum mengena. Dari mulai di bentuknya LANKOR sebagai lembaga yang berwenang melaksanakan kegiatan tersebut hingga sekarang masih belum berjalan maksimal. Fatimah mengatakan bahwa sebagai wujud pelaksanaan standardisasi perlu diadakannya Lembaga Standardisasi Kompetensi Tenaga Keolahragaan (LSKTK) atau pembentukan BSANK. Namun pembentukan BSANK sebagai badan yang diharapkan menjadi lembaga sertifikasi keolahragaan tidak bisa dilakukan karena Kemenpora bukan sebuah Departemen, Kewenangan LSKTK sebagai penyelenggara sertifikasi adalah menerbitkan sertifikat kompetensi tenaga keolahragaan, menetapkan, menangguhkan dan mencabut sertifikat sesuai dengan tingkat kesalahan, menetapkan biaya sertifikat, serta memberikan peringatan, 
pembinaan dan memberikan sanksi kepada pemegang sertifikat yang melakukan pelanggaran.

Dari beberapa hal diatas peneliti mencoba mengkaji permasalahan mengenai pelaksanaan standardisasi dan sertifikasi tenaga bidang keolahragaan pada cabang olahraga. Diharapkan dari kajian ini nantinya dapat memberikan evaluasi dan masukan yang bermanfaat dalam pengembangan kebijakan pelaksanaan standardisasi, dan sertifikasi kedepannya dalam pengembangan sistem keolahragaan nasional

\section{METODE PENELITIAN}

\section{Tujuan Penelitian}

Secara umum penelitian ini bertujuan untuk memperoleh gambaran tentang pelaksanaan standardisasi dan sertifikasi dalam sistem Keolahragaan nasional. Adapun secara khusus tujuan penelitian ini adalah sebagai berikut:

1. Mengetahui pelaksanaan standardisasi dan sertifikasi tenaga keolahragaan pada cabang olahraga yang sudah berjalan selama ini.

2. Mengetahui kendala dan hambatan dalam implementasi pelaksanaan standardisasi dan sertifikasi tenaga keolahragaan pada cabang olahraga .

3. Mengetahui arah kebijakan pelaksanaan sistem standardisasi dan sertifikasi kedepannya.

\section{Pelaksanaan Penelitian}

1. Tempat penelitian

Penelitian di laksanakan beberapa tempat yang dijadikan objek penelitian. Adapun tempat yang dijadikan lokasi/tempat pelaksanaan penelitian yaitu antara lain:

a. Kantor Kementerian Pemuda dan Olahraga Gedung Graha Pemuda Olahraga Lt 8

b. Kantor Koni Pusat di Jakarta

c. Kantor Lembaga Akreditasi Nasional Keolahragaan (Lankor) di Jakarta

d. Kampus Universitas Negeri Jakarta di Jakarta 
e. Kampus Universitas Negeri Semarang di Semarang

f. Kampus Universitas Pendidikan Bandung di Bandung

\section{Metode Penelitian}

Penelitian ini menggunakan metode deskriptif. Metode deskriptif dapat diartikan sebagai prosedur pemecahan masalah yang diselidiki dengan prosedur pemecahan masalah yang diselidiki dengan menggambarkan keadaan subjek penelitian (seorang, lembaga, masyarakat dan lain-lain) pada saat sekarang berdasarkan fakta-fakta yang tampak atau sebagaimana adanya.

Penulis mengumpulkan data dengan metode triangulasi dan mendiskripsikannya dengan di dukung oleh teori sebagai acuan dalam mengintepretasikan hasil penelitian. Untuk kepentingan tersebut di tempuh langkahlangkah sebagai berikut:

1. Memilih lokasi sesuai dengan masalah penelitian yaitu Asisten Deputi Standardisasi, Akreditasi dan Sertifikasi Keolahragaan Kemenegpora Republik Indonesia, pengurus besar cabang olahraga, dan Koni Pusat.

2. Untuk memperoleh makna yang lebih mendalam tentang pelaksanaan program dan kebijakan Asdep SAS dalam sistem keolahragaan nasional.

3. Setelah menetapkan lokasi penelitian, peneliti berusaha memasuki lapangan dengan mengadakan hubungan formal.

4. Mengidentifikasi informan,

5. Mencatat segala sesuatu yang terjadi di lokasi penelitian berdasarkan dokumentasi, observasi dan wawancara.

\section{Instrumen Penelitian}

Instrumen penelitian adalah suatu alat yang digunakan untuk mengukur fenomena alam maupun sosial yang diamati. Instrumen yang digunakan adalah dalam bentuk pedoman observasi, pedoman wawancara dan pedoman dokumentasi yang berisi pertanyaan-pertanyaan penelitian yang bersifat terbuka. Tujuannya adalah 
untuk mengetahui informasi secara mendalam tentang permasalahan yang sedang diteliti.

\section{Teknik Pengumpulan Data}

Untuk mendapatkan data yang dibutuhkan secara mendalam tentang pelaksanaan standarisasi dan sertifikasi dalam sistem keolahragaan nasional, maka peneliti mendalami, mengkaji, menganalisa pendapat, persepsi dan sikap informan dengan observasi, wawancara terstruktur dan studi dokumentasi. Teknik pengumpulan data ini dapat diuraikan sebagai berikut:

1. Teknik observasi digunakan dengan melakukan pengamatan langsung terhadap berbagai kegiatan pelaksanaan di lapangan. Data yang ditemukan berupa dokumen observasi yang diperoleh dari pengamatan lapangan dan berdasarkan catatan lapangan yang diperoleh peneliti.

2. Teknik wawancara dilakukan dengan menggunakan pedoman wawancara terhadap informan yang memiliki kaitan secara langsung dengan pelaksanaan standardisasi, dan Sertifikasi tenaga Keolahragaan Cabang Olahraga .

3. Studi dokumentasi dilakukan untuk memperoleh data-data dan laporan dari Asisten Deputi Standardisasi Akreditasi dan Sertifikasi Keolahragaan, Lembaga Akreditasi Nasional Keolahragaan (Lankor), dan Koni Pusat.

\section{Sumber Data}

Sumber data dalam penelitian deskriptif yang menggunakan teknik pengumpulan data kuesioner atau wawancara maka sumber data disebut dengan responden, yaitu orang-orang yang merespon dan menjawab pertanyaan-pertanyaan peneliti, baik secara lisan maupun tertulis. 
Adapun beberapa responden dalam penelitian ini terdiri atas :

Tabel 2. Narasumber Penelitian

\begin{tabular}{|c|c|c|c|}
\hline No & Tempat Penelitian & Responden & Jabatan/Lembaga \\
\hline 1 & $\begin{array}{l}\text { Kantor Kementerian } \\
\text { Pemuda dan olahraga }\end{array}$ & dr. Fatimah, Sp.KO & $\begin{array}{l}\text { Asdep Standardisasi, } \\
\text { Akreditasi \& } \\
\text { Sertifikasi } \\
\text { keolahragaan/Menpor } \\
\text { a }\end{array}$ \\
\hline 2 & $\begin{array}{l}\text { Kantor Komite Olahraga } \\
\text { Nasional Indonesia } \\
\text { (KONI) }\end{array}$ & $\begin{array}{l}\text { Arsyad Achmadin, } \\
\text { SH, M.Si }\end{array}$ & $\begin{array}{l}\text { Wakabid Organisasi/ } \\
\text { KONI Pusat }\end{array}$ \\
\hline 3 & Kantor Lankor & $\begin{array}{c}\text { Prof. Husein } \\
\text { Argasasmitha, MA }\end{array}$ & Ketua /Lankor \\
\hline \multirow[t]{3}{*}{4} & $\begin{array}{l}\text { Pengurus Cabang } \\
\text { Olahraga }\end{array}$ & $\begin{array}{c}\text { Drs. Ria } \\
\text { Lumintuarso, M.Si. }\end{array}$ & $\begin{array}{c}\text { Litbang/PB PASI dan } \\
\text { RDC }\end{array}$ \\
\hline & & Bp. Dwi Priyono & $\begin{array}{c}\text { Komisi Perwasitan/PB } \\
\text { PASI }\end{array}$ \\
\hline & & bp. Umaryono & Komisi Bidang Data \\
\hline \multirow[t]{3}{*}{5} & Wilayah penelitian & \multirow{2}{*}{ Pelatih dan wasit } & Pelatih \\
\hline & & & Wasit \\
\hline & & & Ketua PPLM Jakarta \\
\hline
\end{tabular}

\section{Teknik Analisa Data}

Analisis data menggunakan analisis deskriptif kualitatif. Analisa data merupakan langkah-langkah yang dilakukan setelah pengumpulan data, secara garis besar analisis data dilakukan menurut tahapan Data collection, Reduksi data, Display data, dan Pengambilan kesimpulan dan verifikasi

\section{HASIL PENELITIAN DAN PEMBAHASAN}

\section{Hasil Penelitian}

1. Pelaksanaan Standardisasi, Akreditasi dan Sertifikasi Tenaga Keolahragaan

Dari hasil penelitian pelaksanaan sertifikasi tenaga keolahragaan menunjukkan adanya 2 prosedur dalam pelaksanaan sertifikasi yaitu mengacu pada 
dua prosedur yang dijalankan oleh menpora dan oleh Pengurus Besar Cabang Olahraga. Pola Sertifikasi yang dilakukan oleh 2 lembaga tersebut sebenarnya sama yaitu pemberian pengakuan terhadap pemenuhan standar kompetensi tenaga keolahragaan.

Fatimah (Wawancara) sebagai Asisten Deputi Standardisasi, Akreditasi dan Sertifikasi Keolahragaan (Asdep SAS) menguraikan bahwa Asdep SAS memiliki peran yang sangat penting dalam pelaksanaan standarisasi, Fungsi dari Asdep SAS adalah melaksanakan amanat Undang-Undang Nomor 3 Tahun 2005 tentang Sistem Keolahragaan Nasional, salah satunya secara tegas menyampaikan tentang standar nasional keolahragaan.

Husein Argasasmita (Wawancara) selaku Ketua Harian Lembaga Akreditasi Nasional Keolahragaan (LANKOR) menyatakan bahwa pelaksanaan standardisasi yang berjalan selama ini berjalan masih belum jelas lembaga yang menaunginya. Hal ini terkait dengan terbenturnya pembentukan BSANK sebagai lembaga independen pelaksana sistem standarisasi keolahragaan yang strategis.

Ria Lumintuarso (Wawancara) menyatakan bahwa pelaksanaan standarisasi yang berjalan dicabang olahraga adalah mengacu pada induk organisasi internasional. Pihaknya mengaku tidak memiliki peran dan fungsi dan wewenang secara khusus dalam pelaksanaan standardisasi tenaga keolahragaan.

Hal yang hampir sama diungkapkan pihak Komite Olahraga Nasional Indonesia (KONI) Pusat, Arsyad Ahmadin yang menjabat sebagai wakabid organisasi menyampaikan mengenai peran, fungsi dan wewenang KONI dalam pelaksanaan standardisasi keolahragaa. Menurutnya KONI hanya memiliki fungsi memantau standard nasional keolahragan dan tidak memiliki kepentingan secara langsung dengan pelaksanaan standarisasi keolahragaan. Dalam implementasinya KONI lebih menilai seseorang tenaga keolahragaan dari hasil prestasi yang dicapai, bukan dari standard baku yang diperoleh.

Dari hasil wawancara dengan pelatih dan wasit dari cabang olahraga memunculkan beberapa pendapat antara lain sebagai berikut : 
1. Pelaksanaan standardisasi tenaga keolahragaan yang ada di cabang olahraga merupakan hal yang masih baru, dan belum terlihat implementasinya.

2. Pelaksanaan sertifikasi yang selama ini ada pada cabang olahraga mengacu pada induk cabang organisasi masing-masing cabang olahraga dan federasi internasional cabang olahraga.

3. Pendapat mengenai pelaksanaan standarisasi tenaga keolahragaan cabang olahraga adalah perlu untuk dilaksanakan dan di implementasikan secara konsisten.

4. Perhatian terhadap tenaga keolahragaan baik wasit, pelatih dan tenaga keolahragaan harus lebih ditingkatkan oleh pemerintah untuk dapat meningkatkan kualitas dari tenaga keolahragaan itu sendiri.

5. Perlu lembaga independen pelaksana standardisasi agar pelaksanaanya bisa lebih sempurna.

Standar Nasional Keolahragaan meliputi Standar Kompetensi Tenaga Keolahragaan, Standar Isi Program Penataran/Pelatihan Tenaga Keolahragaan, Standar Prasarana dan Sarana Olahraga, Standar Pengelolaan Organisasi Keolahragaan, Standar Penyelenggaraan Keolahragaan, dan Standar Pelayanan Minimal Keolahragaan. Standar Nasional Keolahragaan tersebut digunakan sebagai pedoman atau acuan program standardisasi, akreditasi dan sertifikasi keolahragaan.

Sampai saat ini sudah Kementerian Pemuda dan Olahraga sudah memfasilitasi Penyusunan Rancangan Standar Kompetensi Tenaga Keolahragaan sebanyak 13 Rancangan Standar Kompetensi Tenaga Keolahragaan Tingkat Dasar, yaitu :
a) Instruktur Kebugaran Tingkat Dasar
b) Pelatih Atletik Tingkat Dasar
c) Pelatih Bulutangkis
d) Pelatih Pencak Silat
e) Pelatih Olahraga di Sekolah
f) Wasit Atletik
g) Wasit Bulutangkis 
h) Wasit Pencak Silat

i) Prasarana Olahraga

j) Pelatih Dayung

k) Pelatih Panahan

1) Pelatih Gulat

m) Pelatih Senam

2. Hambatan dan Kendala pelaksanaan Standardisasi, Akreditasi dan Sertifikasi

Berikut ini deskripsi hasil data penelitian mengenai kendala dan hambatan pelaksanaan Standardisasi dan sertifikasi keolahragaan :

a. Anggaran yang masih terbatas

b. Ketidakjelasan fungsi dan kewenangan dari pelaksanaan standardisasi dan sertifikasi

c. Kendala SDM Pelaksana dan Objek sasaran dari pelaksanaan standarisasi dan sertifikasi

d. Ruang lingkup kajian dari tenaga keolahragaan itu sendiri

e. Belum Sinerginya lembaga stake holder bidang keolahragaan

\section{Pembahasan}

Sistem Keolahragaan Nasional adalah keseluruhan aspek keolahragaan yang saling terkait secara terencana,sistematis, terpadu, dan berkelanjutan sebagai satu kesatuan yang meliputi pengaturan, pendidikan, pelatihan,pengelolaan, pembinaan, pengembangan, dan pengawasan untuk mencapai tujuan keolahragaan nasional. Sistem Keolahragaan Nasional seperti yang tertuang dalam Undang-undang Nomor 3 tahun 2005 perlu ditindaklanjuti dengan pengembangan standar dibidang keolahragaan, sistem sertifikasi dan sistem akreditasi.

Dalam penelitian, penulis mengkaji pelaksanaan standardisasi dan sertifikasi dalam sudut pendang manajemen olahraga dalam 3 aspek kajian manajemen olahraga yaitu : manajemen organisasi /lembaga, manajemen kebijakan dan manajemen even a. Manajemen Organisasi/Lembaga 
Manajemen organisasi/lembaga dibagi dalam 2 ruang lingkup yaitu manajemen organisasi pemerintah (Government) dan non pemerintah (non government). Peneliti menilai bahwa perlu adanya pembagian kewenangan dan fungsi dari lembaga-lembaga yang ada dalam membuat dan menjalankan sistem standardisasi secara jelas dan proporsional.

Peneliti menilai bahwa masih adanya kebingungan dari masing-masing lembaga pelaksana standardisasi dan sertifikasi serta akreditasi baik dari pemerintah sendiri maupun unsur independen atau swasta yang terkait. Hal ini dilihat dari program kerja yang dilaksanakan oleh beberapa lembaga pelaksana standardisasi, akreditasi maupun sertifikasi. Sebagai contoh dalam pelaksanaan standardisasi yang dilakukan dicabang olahraga . Penentuan standar tingkat dalam kepelatihan maupun perwasitan yang ada masih berbeda-beda dan tidak saling berkesinambungan.

Dalam analisis kajian manajemen organisasi atau lembaga peneliti mengkaji dari sudut pandang fungsi, tugas, kewenangan dan tanggung-jawab dari masingmasing lembaga pelaksana standardisasi dan sertifikasi. Berikut hasil kajian peneliti mengenai lembaga pelaksana standardisasi dan sertifikasi dari sudut pandang peneliti berdasarkan hasil temuan penelitian :

1) Pemerintah.

a) Kemenpora

Kementerian pemuda dan olahraga sebagai lembaga pemerintah memiliki tanggung-jawab dalam pencapaian standard kompetensi tenaga keolahragaan, namun tidak memiliki fungsi dan wewenang dalam pelaksanaanya dilapangan. Peran pemerintah hanya sebagai fasilitator dan pengambil kebijakan yang berkaitan dengan pelaksanana dan pemberlakuan standar yang telah ditetapkan.

b) Dinas olahraga terkait

Dinas Olahraga terkait dalam hal ini adalah instansi pemerintah seperti Dinas Pemuda dan Olahraga atau Dinas yang masih membawahi olahraga seperti Pemerintah Daerah dan Dinas Pendidikan. Dinas tersebut merupakan lembaga pelaksana kebijakan yang ada ditingkat daerah atau dibawah kewenanganya. 


\section{2) Non Pemerintah}

a) $\mathrm{KONI}$

Koni memiliki tanggung-jawab dalam meningkatkan kualitas sumber daya manusia dibidang keolahragaan. namun tidak memiliki fungsi dan kewenangan ataupun tugas dalam pelaksanaan standardisasi dan sertifikasi. Dalam hal ini KONI sebagai lembaga swasta/nonpemerintah tetap harus memiliki arah kebijakan yang mengarah pada peningkatan standard kompetensi tenaga keolahragaan.

b) Induk organisasi cabang olahraga

Induk cabang olahraga merupakan unsur penting dalam pelaksanaan standardisasi dan sertifikasi tenaga keolahragaan. hal ini karena Induk organisasi cabang olahraga memiliki kepentingan langsung dalam penggunaan jasa tenaga keolahragaan.

c) Fakultas Ilmu Keolahragaan

Elemen lain yang juga memiliki tanggung-jawab dalam menghasilkan tenaga keolahragaan yang memiliki standard kompetensi yang memadai adalah Fakultas Ilmu Keolahragaan. Disinilah sebenarnya wadah yang tepat untuk menghasilkan tenaga keolahragaan yang berkualitas.

d) Manajemen Kebijakan

Sistem standardisasi di bidang keolahragaan nasional harus terselenggara dengan baik agar dapat diimplementasikan oleh pelaku olahraga sehingga dapat menghasilkan para olahragawan yang berprestasi didukung dengan sarana dan prasarana yang memadai dan memenuhi standar internasional untuk penyelenggaraan even olahraga internasional dan berkembangnya industri dibidang olahraga di Indonesia.

Arah kebijakan dari pemerintah diimplementasikan melalui program-program yang dijalankan oleh kementerian Pemuda dan Olahraga yang dalam hal ini diperankan oleh Asisten Deputi Standardisasi, Akreditasi dan Sertifikasi yang kemudian melakukan fasilitasi terhadap lembaga-lembaga dan instansi terkait sebagai pelaksana dan pengguna dari standar yang telah dibuat. 
Pelaksanaan standandarisasi menurut Peraturan Pemerintah No 16 Tahun 2007 tentang Penyelanggaraan Olahraga diamanahkan kepada Badan Standardisasi Akreditasi Nasional Keolahragaan (BSANK) . disebutkan bahwa dalam rangka pengembangan, pemantauan dan pelaporan pencapaian standar nasional, pemerintah membentuk Badan Standardisasi, Akreditasi Nasional Keolahragaan yang disingkat menjadi BSANK. BSANK dalam menjalankan fungsinya bertanggung-jawab pada Menteri dan bekerja secara mandiri dan profesional.

\section{b. Manajemen Even Olahraga}

Dalam kajian manajemen even olahraga, analisis mengenai pelaksanaan standardisasi dan sertifikasi tenaga keolahragaan adalah bagaimana pelaksanaan even olahraga sebagai wadah dari penggunaan tenaga keolahragaan itu sendiri. Feedback atau umpan baliknya adalah bagaimana tenaga keolahragaan dapat memiliki nilai jual dalam sebuah even/kejuaraan olahraga. Sehingga pengelolaan dan penyelenggaraan even-even olahraga harus memiliki aturan dan sistem yang mengacu dan menguntungkan pada pemberlakuan standar kompetensi keolahragaan.

Pelaksanaan standardisasi, akreditasi dan sertifikasi diperlukan untuk meningkatkan kualitas dan kompetensi tenaga keolahragaan sebagai profesi. Peningkatan kualitas dan mutu tenaga keolahragaan akan memberikan dampak signifikan dalam pengembangan keolahragaan nasional dimana tenaga olahraga akan benar-benar menjadi sebuah profesi yang “Terhormat dan bermartabat” dimata masyarakat. Tenaga olahraga tidak lagi menjadi sebuah kegiatan "Kerja bakti” ataupun "Pekerjaan sampingan" selain menjadi guru atau dibawah pekerjaan lainnya.Namun hal tersebut harus dicapai melalui pencapaian standar nasional yang jelas.

Adapun sintesis pola pengembangan kajian manajemen olahraga dan lembaga pelaksananya menurut peneliti adalah sebagai berikut : 


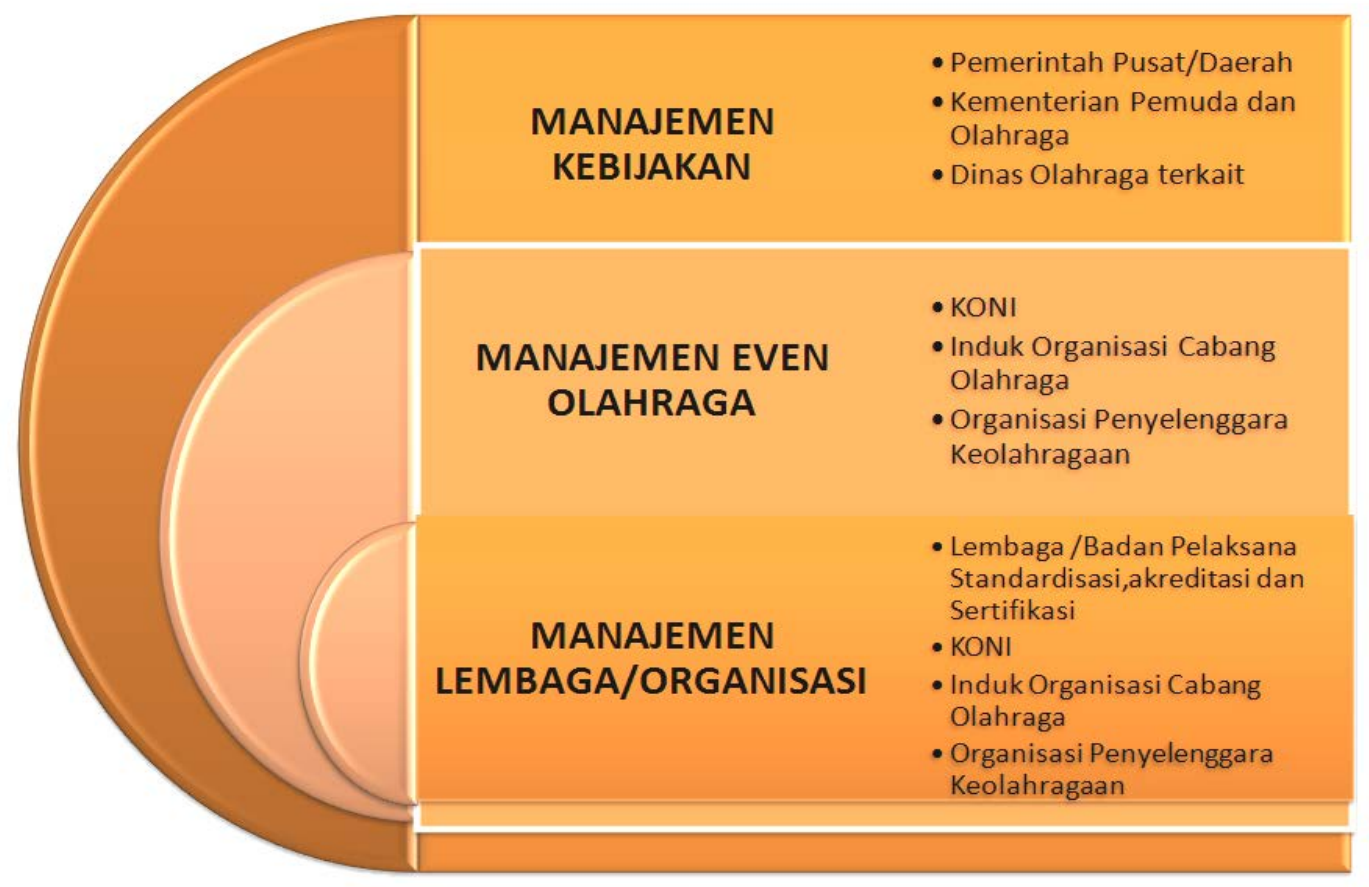

Gambar. Sintesis pola pengembangan Manajemen Pelaksanaan Standardisasi dan Sertifikasi Tenaga Keolahragaan

Pelaksanaan standardisasi, akreditasi dan sertifikasi diperlukan untuk meningkatkan kualitas dan kompetensi tenaga keolahragaan sebagai profesi. Peningkatan kualitas dan mutu tenaga keolahragaan akan memberikan dampak signifikan dalam pengembangan keolahragaan nasional dimana tenaga olahraga akan benar-benar menjadi sebuah profesi yang “Terhormat dan bermartabat” dimata masyarakat. Tenaga olahraga tidak lagi menjadi sebuah kegiatan "Kerja bakti" ataupun "Pekerjaan sampingan” selain menjadi guru atau dibawah pekerjaan lainnya. Sehingga diperlukan sebuah kebijakan baik pemerintah pusat maupun daerah yang mengarah pada pengembangan sektor swasta (non pemerintah) untuk dapat berperan dalam pengembangan industry olahraga di Indonesia

Menjawab pertanyaan mengenai relevansi pelaksanaan standardisasi dan sertifikasi tehadap ketenagakerjaan di Indonesia akan bergantung dengan kebijakan 
dari pemerintah dan peran serta dari pihak swasta dalam pengembangan keolahragaan di Indonesia.

Secara nyata dapat kita analisa apabila dari 3000 lulusan jurusan/fakultas olahraga pertahun dapat disalurkan kedalam profesi tenaga keolahragaan seperti yang tercantum dalam undang-undang no 3 tahun 2005, maka akan sangat berdampak pada penurunan tingkat penggangguran di Indonesia. Dan apabila sistem pelaksanaan standardisasi, akreditasi dan sertifikasi dapat dilaksanakan secara konsisten dan berkelanjutan tentu akan berdampak pada peningkatan kualitas pembinaan prestasi olahraga yang ada di Indonesia.

\section{KESIMPULAN DAN SARAN}

\section{Kesimpulan}

Berikut simpulan hasil penelitian dari pelaksanaan Standarisasi dan sertifikasi keolahragaan berdasarkan temuan hasil penelitian :

1. Pelaksanaan Standardisasi dan Sertifikasi Tenaga Keolahragaan pada Cabang Olahraga Atletik

a. Lemahnya sistem manajemen implementasi pelaksanaan standardisasi, akreditasi dan sertifikasi pada cabang olahraga atletik

b. Terdapat dua prosedur pelaksanaan standardisasi, yaitu yang dilakukan oleh kemenpora dan PB PASI dan terdapat dua prosedur sertifikasi yang dilaksanakan oleh PB PASI dan LANKOR

c. Rendahnya pemahaman masyarakat/insan olahraga terhadap pelaksanaan standardisasi, akreditasi dan sertifikasi tenaga keolahragaan

d. Standarisasi dan sertifikasi yang didukung dengan sistem akreditasi yang belum berjalan secara konsisten.

2. Kendala dan Hambatan Pelaksanaan Standardisasi dan Sertifikasi Tenaga Keolahragaan pada Cabang Olahraga Atletik

a. Anggaran yang masih terbatas 
b. Ketidakjelasan fungsi dan kewenangan dari pelaksanaan standardisasi dan sertifikasi

c. Kendala SDM Pelaksana dan Objek sasaran dari pelaksanaan standarisasi dan sertifikasi

d. Ruang lingkup kajian dari tenaga keolahragaan itu sendiri

e. Belum Sinerginya lembaga stake holder bidang keolahragaan

3. Arah Kebijakan Pelaksanaan Standardisasi dan Sertifikasi Tenaga Keolahragaan Arah kebijakan Standardisasi dan Sertifikasi Keolahragaan adalah tercapainya standard nasional keolahragaan dengan tujuan untuk menjamin mutu penyelenggaraan sistem keolahragaan. Tercapainya 50\% tenaga keolahragaan yang telah tersertifikasi, 50\% isi program/pelatihan tenaga keolahragaan terstandarisasi, 70\% prasarana dan sarana keolahragaan terakreditasi, 50\% organisasi keolahragaan terakreditasi, 70\% penyelenggaraan keolahragaan terakreditasi, dan $40 \%$ pelayanan minimal terstandarisasi.

\section{Saran}

Berdasarkan simpulan penelitian, peneliti merekomendasikan beberapa saran dalam pelaksanaan Standarisasi dan Sertifikasi tenaga keolahragaan sebagai berikut :

1. Standarisasi dan sertifikasi yang didukung dengan sistem akreditasi yang accountable merupakan sebuah proses yang sangat perlu dijalankan untuk meningkatkan kompetensi tenaga keolahragaan maupun sistem keolahragaan secara umum. Sehingga memerlukan sistem manajemen pelaksanaan yang baik.

2. Luasnya ruang lingkup, karakteristik kecabangan dari tenaga keolahragaan, Serta minimnya SDM penunjang merupakan tantangan terbesar dalam pelaksanaan standarisasi dan sertifikasi, sehingga memerlukan sinergi dari berbagai stake holder keolahragaan yang ada.

3. Kerancuan fungsi, wewenang dan tanggung-jawab dari masing-masing stake holder dalam pelaksanaan standarisasi dan sertifikasi menjadi permasalahan yang harus diselesaikan sebelum melangkah lebih jauh. Dan solusi yang paling tepat 
adalah dengan realisasi pembentukan badan independen pelaksana Standarisasi, Akreditasi dan Sertifikasi seperti Badan Standarisasi, Akreditasi Nasional Keolahragaan (BSANK), dan lembaga sertifikasi lainnya.

4. Banyaknya standard kompetensi tenaga keolahragaan yang harus disusun harus disikapi oleh berbagai pihak salah satunya adalah dengan menentukan prioritas cabang olahraga dan klasifikasi dari tenaga keolahragaan di tiap cabang olahraga.

\section{DAFTAR PUSTAKA}

Badan Standardisasi Nasional, 2009. Salinan Pedoman Sistem Standardisasi Nasional.

Guidelines for Development of Regional Model Competency Standards (RMCS), http://mengerjakantugas.blogspot.com/2009/03/pengertian-kompetensi.html http://www.menkokesra.go.id/content/view/3728/

ISO Directive, 2008. Part 1 - Procedure for the technical work, sixth edition.

ISO Directive, 2004. Part 2 - Rules for the structure and drafting of International Standard, fifth edition.

Kemenegpora, 2005. Undang-undang Sistem Keolahragaan Nasional No 3 Tahun 2005. Jakarta : Kemenegpora.

Kemenegpora, 2009. Pedoman Standardisasi Nasional Keolahragaan. Jakarta : Kemenegpora.

BNSP, 2009. Materi Pelatihan Perumusan Standar Kompetensi Profesi Bidang Keolahragaan. Jakarta:Kemenpora. 2009

Paland, R, 2007. Competency Management, Jakarta.PPM.

Panitia Teknis Perumusan Standar Nasional Indonesia (SNI), PSN-02 - 2005: Badan Standardisasi Nasional Indonesia (BSN). 
BNSP, 2005. Pedoman Penyusunan Standar Kompetensi Kerja Nasional Indonesia, BNSP.103-2005. Jakarta. BNSP.

Pengembangan Standar Nasional Indonesia (SNI), PSN-01 - 2005: Badan Standardisasi Nasional Indonesia (BSN).

Peraturan Menteri Tenaga Kerja Dan Transmigrasi Nomor: PER. 21/MEN/X/2007 Tentang Tata Cara Penetapan Standar Kompetensi Kerja Nasional Indonesia

Peraturan Pemerintah RI No 16 Tahun 2007, Tentang Penyelenggaraan Olahraga.

Peraturan Pemerintah (PP) No. 23 Tahun 2004, tentang Badan Nasional Standardisasi Profesi

Subroto, 2009. Tak Ada Standar Akreditasi dan Sertifikasi, Olahraga Terpuruk (Artikel).

Plunkett, 2006. Sport Industry Training Package, Australian National Training Authority (ANTA). USA : Plunkett Research.ltd.

Suharsimi. Arikunto, 2006. Prosedur Penelitian (Suatu PendekatanPraktik) Edisi Revisi VI. Jakarta ; PT Rineka Cipta. 